\title{
ANALISIS KEBERLANJUTAN PENGELOLAAN LIMBAH DI INSTALASI KARANTINA HEWAN (IKH) RUMINANSIA BESAR
}

\section{Analysis of Waste Management Sustainability in Animal Quarantine Installation in Ruminansia Besar}

\author{
N. Zainuddin ${ }^{1}$, Khariri ${ }^{2}$, M. S. Maarif ${ }^{3}$, E. Riani ${ }^{4}$, S. M. Noor ${ }^{5}$ \\ ${ }^{1}$ Departemen Pengelolaan Sumber Daya Alam dan Lingkungan, Institut Pertanian Bogor \\ ${ }^{2}$ Puslitbang Biomedis dan Teknologi Dasar Kesehatan, Badan Litbang Kesehatan \\ ${ }^{3}$ Sekolah Bisnis, Institut Pertanian Bogor \\ ${ }^{4}$ Departemen Pengelolaan Sumber Daya Perikanan, Fakultas Perikanan dan Kelautan, Institut Pertanian \\ Bogor \\ ${ }^{5}$ Balai Besar Penelitian Veteriner, Badan Penelitian dan Pengembangan Pertanian \\ Email: arie.tegale@gmail.com
}

Diterima: 4 April 2019; Direvisi: 8 April 2020; Disetujui: 25 Juni 2020

\begin{abstract}
Indonesia regulates post-entry observations of slaughter animals through the Animal Quarantine Installation (AQI). For the continuation of the existence of AQI, it is necessary to carry out an analysis of the sustainability of AQI waste management, because errors in waste management can cause disease and environmental pollution. The purpose of this study is to evaluate and determine the sustainability of AQI based on 5 dimensions, namely the dimensions of ecology, economics, technology, social, and institutions. AQIs taken as research objects are one government AQI and one private AQI. The study was conducted by observation. The results of the observations were analyzed using a modification of the Rap-fish method with Multidimensional Scaling called Rap-AQI. The results showed the sustainability of private AQI in multidimensional aspects showing a sustainability index of 57.47, each indicated from the dimensions of ecology (54.17), economy (70.12), social (57.47), technology (54.89), and institutional (50,73). Whereas the government's AQI showed unsustainable results with a sustainability index of 45.02, each from ecological dimensions (49.24), economic (45.30), social (55.77), technology (29.27) and institutional dimensions (43.53). Leverage attribute analysis shows that of 54 existing attributes, there are 12 sensitive attributes as a key factor in the sustainability of AQI waste management.
\end{abstract}

Keywords: Sustainability, animal quarantine installation, atribute, dimention

\begin{abstract}
ABSTRAK
Indonesia mengatur pengamatan pasca-masuk hewan potong melalui Instalasi Karantina Hewan (IKH). Pemerintah telah melakukan kebijakan untuk pencegahan atau meminimalkan risiko penyebaran organisme penyakit hewan dan zoonosis pada kegiatan impor hewan dipintu masuk yaitu IKH. Untuk keberlanjutan keberadaan IKH, perlu dilakukan analisis keberlanjutan pengelolaan limbah IKH, karena kesalahan dalam pengelolaan limbah dapat menimbulkan dampak penyakit dan pencemaran lingkungan. Tujuan dari penelitian ini adalah melakukan evaluasi dan menentukan keberlanjutan IKH berdasarkan 5 dimensi, yaitu dimensi-dimensi ekologi, ekonomi, teknologi, sosial dan kelembagaan. IKH yang diambil sebagai objek penelitian adalah satu IKH pemerintah dan satu IKH swasta. Penelitian dilakukan dengan pengamatan. Hasil pengamatan dianalisa dengan menggunakan modifikasi metode Rap-fish dengan Multidimensional Scaling yang disebut Rap-IKH. Hasil penelitian menunjukkan keberlanjutan IKH swasta dalam multidimensi aspek menunjukkan indeks keberlanjutan 57,47, masing-masing ditunjukkan dari dimensi ekologi (54,17), ekonomi (70,12), sosial (57,47), teknologi (54,89), dan kelembagaan $(50,73)$. Sedangkan IKH pemerintah menunjukkan hasil yang kurang berkelanjutan dengan indeks keberlanjutan 45,02, masing-masing dari dimensi ekologi (49,24), ekonomi (45,30), sosial $(55,77)$, teknologi $(29,27)$ dan dimensi kelembagaan (43,53). Analisis leverage atribut menunjukkan bahwa dari 54 atribut yang ada, terdapat 12 atribut sensitif sebagai faktor kunci keberlanjutan pengelolaan limbah IKH.
\end{abstract}

Kata kunci: Keberlanjutan, instalasi karantina hewan, atribut, dimensi 


\section{PENDAHULUAN}

Instalasi Karantina Hewan yang selanjutnya disebut IKH adalah suatu bangunan berikut peralatan dan lahan serta sarana pendukung yang diperlukan sebagai tempat untuk melakukan tindakan karantina (Permentan No. 70, 2015). Fungsi dan tugas IKH adalah untuk mencegah masuk, tersebar, dan keluarnya Hama dan Penyakit Hewan Karantina (HPHK). HPHK adalah semua hama, hama penyakit, dan penyakit hewan yang berdampak pada sosio-ekonomi nasional dan perdagangan internasional serta menyebabkan gangguan kesehatan masyarakat veteriner yang dapat digolongkan menurut tingkat risikonya (Peraturan Pemerintah No. 82, 2000). IKH merupakan garda terdepan dalam mencegah masuk, keluarn dan tersebarya berbagai hama dan penyakit hewan termasuk pada jenis hewan ruminansia. Akan tetapi IKH dapat juga menimbulkan dampak terhadap lingkungan dan masyarakat sekitar yang disebabkan oleh limbah yang dihasilkan, yaitu limbah padat, limbah cair dan bau yang timbul dari kotoran hewan. Meskipun demikian limbah padat dapat memberikan dampak positif berupa nilai ekonomi, yakni limbah yang dihasilkan dapat dimanfaatkan sebagai bahan pembuatan pupuk organik dan media tanam. Namun demikian pemanfaatan limbah dapat berdampak negatif pada aspek sosial seperti konflik keberadaan IKH dengan masyarakat sekitarnya. Dampak sosial lain adalah meningkatnya keresahan masyarakat sekitar, karena terganggunya rasa aman, merasa terancam kemungkinan adanya penularan berbagai penyakit hewan ke hewan ternak mereka atau ke manusia serta menurunnya rasa nyaman karena bau dan suara bising yang ditimbulkan dari hewan-hewan di karantina tersebut (Permentan No. 14, 2016).

Pada tahun 2016, Badan Karantina Pertanian mencatat pemusnahan tiga sapi impor di IKH yang terinfeksi paratuberculosis. Pada tahun 2016 dan 2019 terdapat dua sapi impor dari Australia terinfeksi brucellosis yang merupakan penyakit zoonosis (Permentan No. 14, 2016). Penelitian Danial et al., (2010), menyebutkan sekitar 60 sampel urin sapi yang impor dari Australia mengandung residu hormon Trenbolone Asetat (TBA) dengan berbagai kadar konsentrasi. Residu hormon TBA dengan konsentrasi $<2$ ppb terdeteksi pada 37 sampel $(61,67 \%)$, konsentrasi hormom TBA 2-4 ppb terdeteksi dalam 7 sampel (7\%), dan konsentrasi hormon TBA > 4 ppb terdeteksi pada 16 sampel $(26,67 \%)$ (Danial, Latif, \& Indrawati, 2015). Selain itu jika ada perlakuan pengobatan menggunakan antibiotik terhadap hewan karantina selama karantina dapat berpotensi menyebabkan pencemaran lingkungan dan menyebabkan resistensi abtibiotik (Loisa, Lukman, \& Latif, 2016).

Disamping hal tersebut diatas mikroorganisme patogen yang dikeluarkan melalui feses atau urin, ekskreta tersebut mengandung mikroorganisme yang pathogen pada manusia. Di dalam IKH tidak menutup kemungkinan adanya sejumlah besar patogen terbuang melalui selokan-selokan yang dibuat di sekitar kandang menyebar ke lingkungan luar melalui aliran sungai. Jenis mikroorganisme yang sudah sering ditemukan dan mencemari air sungai adalah Eschericia coli dan Salmonella sp. (Widiastuti, Pramestuti, Setiyani, \& Rahayu, 2013). Hutchison et al,. (2004) dapat mengisolasi bakteri Salmonella sp, Listeria sp, dan Campylobacter spp dan Escherichia coli $\mathrm{O} 157$ pada limbah ternak dengan rata rata $10^{6}$ per gram feses sebelum tersebar ke tanah (Hutchison, Walters, Avery, Synge, \& Moore, 2004). Penelitian Zainuddin dan tim menunjukkan bahwa terjadi pencemaran air limbah dari 5 lokasi IKH yang diteliti(Zainudin, 2019). Selain itu jumlah bakteri Coliform dan Eschericia coli melebihi baku mutu usaha peternakan yang telah ditentukan melalui Peraturan Menteri Lingkungan Hidup dan Kehutanan (Peraturan Menteri Lingkungan Hidup No. 1815, 2014).

Permasalahan sosial yang muncul yaitu $37,5 \%$ mayarakat mengeluhkan akan dampak buruk dari kegiatan usaha IKH. Sebagian besar IKH mengabaikan penanganan limbah, bahkan terkadang membuang limbah ke sungai sehingga mengakibatkan pencemaran lingkungan. Limbah peternakan yang dihasilkan seperti feses, urin, sisa pakan, serta air dari pembersihan ternak dan kandang menimbulkan pencemaran yang memicu 
protes dari warga sekitar. Dampak limbah tersebut dapat berupa bau kotoran yang menyengat, banyaknya lalat dan nyamuk sampai keluhan gatal-gatal ketika mandi di sungai yang tercemar limbah peternakan. Untuk itu persyaratan yang harus dipenuhi IKH adalah, harus memiliki fasilitas pengolahan limbah dan harus memiliki dokumen pengolahan limbah sehingga berbagai risiko yang ditimbulkan dapat dikendalikan dan aman bagi lingkungan. Hasil penelitian menunjukkan bahwa IKH yang ada sudah mempunyai tempat penampungan limbah kotoran ternak mencapai $93,8 \%$. Sebanyak 6,2\% IKH masih membuang limbah kotoran hewan ke parit atau sungai (Santoso, 2012).

Penanganan hewan dengan kelengkapan sarana dan prasarana IKH serta sistem pengelolaan limbah yang ada juga menjadi bagian yang sangat penting dalam keberlanjutan keberadaan IKH dilingkungan tersebut. Hal yang harus dipenuhi supaya keberadaan IKH dapat berlanjut adalah tercapainya keseimbangan antara berbagai dimensi pengelolaan seperti yang disyaratkan dalam pembangunan berkelanjutan. Aspek ekonomi kegiatan tersebut dapat memberikan keuntungan ekonomi baik berupa peningkatan pendapatan maupun pertumbuhan ekonomi. Dari aspek sosial, kegiatan tersebut dapat memberikan kenyamanan dan pemerataan sosial serta keadilan bagi masyarakat sekitar seperti kesempatan dan peluang bekerja, serta sebagai wadah komunikasi dan sosialisasi (Santoso, 2012).

Aspek ekologi kegiatan tersebut dapat menjaga fungsi-fungsi lingkungan, seperti; badan air yang tidak tercemar. Suatu kegiatan pembangunan dinyatakan dapat berkelanjutan jika persyaratan ekonomi, ekologi, dan sosial dapat terpenuhi (Serageldin, 1996). Dukungan faktor-faktor pembangunan seperti terpeliharanya proses ekologi yang esensial, tersedianya sumber daya yang cukup, lingkungan sosial-budaya dan ekonomi yang sesuai menjadi kunci keberlanjutan (Soemarwoto, 2014).

Mengingat pentingnya keberadaan IKH, maka perlu dilakukan kajian terhadap status keberlanjutan dari pengelolaan limbah IKH dengan 5 dimensi persyaratan keberlanjutan, yaitu dimensi ekologi, ekonomi, sosial, teknologi dan kelembagaan (Bakeri, J. P, Riani, \& Sutjahjo, 2012). Diharapkan hasil dari kajian 5 dimensi persyaratan keberlanjutan pengelolaan limbah IKH ini dapat menjadi bahan evaluasi kebijakan terhadap penetapan IKH oleh pemerintah.

\section{BAHAN DAN CARA}

Kegiatan kajian dilakukan di IKH pemerintah yaitu IKH SKP Kelas I Cilacap dan IKH pihak lain (swasta) yaitu PT Legok Makmur Lestari yang berlokasi di Desa Bojong Kramat, Kecamatan Legok Tangerang Banten merupakan perusahaan dengan kapasitas IKH sebesar 7056 ekor. Penelitian dilaksanakan selama empat bulanJanuari sampai dengan April 2018. Untuk mengetahui persyaratan keberlanjutan pengelolaan limbah IKH, data yang dikumpulkan meliputi data primer dan data sekunder.

Data primer diperoleh melalui wawancara mendalam (in-depth interview) dan pengisian kuisioner yang telah disusun berdasarkan judgement knowledge dari pakar. Ketentuan pakar yang terpilih adalah berdasarkan kriteria yang telah disusun oleh Ramadan yaitu, (a) pengalaman dan kompetensi yang dimiliki pakar sesuai bidang yang diteliti, (b) reputasi/ jabatan pakar terkait dengan bidang yang diteliti, (c) kredibilitas pakar, (d) komitmen pakar pada permasalahan yang diteliti, (e) pakar tidak berpihak (netral) dan bersedia menerima pendapat responden lain, (f) bersedia dimintai pendapat dan (g) pakar memahami dan berada pada lokasi penelitian.

Berdasarkan kriteria tersebut, ditetapkan 25 orang pakar terpilih yang terdiri dari 5 orang $(20 \%)$ dari unsur kementerian/kelembagaan pemerintah pusat yaitu Kementerian Pertanian, Kementerian Lingkungan Hidup dan Kehutanan; 4 orang (16\%) dari pemerintah daerah yang terdiri dari Dinas Lingkungan Hidup Daerah (BLHD) Cilacap dan Tangerang, Dinas Tata Ruang dan Bangunan Cilacap dan Tangerang; 6 orang (24\%) adalah pemilik/pimpinan perusahaan IKH dan atau pengelola IKH; 2 orang (8\%) dari perguruan 
Tinggi/Akademisi; 8 orang $(32 \%)$ dari masyarakat, pemuka agama disekitar IKH.

Adapun latar belakang pendidikan pakar adalah 10 orang $(33,33 \%)$ berlatar belakang pendidikan Sekolah Menengah Atas (SMA), 6 orang $(20 \%)$ berlatar belakang sarjana strata 1 (S1), 6 orang (20\%) berlatar belakang sarjana strata 2 (S2) dan 8 orang $(26.67 \%)$ berlatar belakang sarjana strata 3 (S3).

Data sekunder adalah data yang diperoleh dari dokumen atau pencatatan lain yang dilakukan melalui penelusuran pustaka yang terkait dengan pengelolaan IKH. Sumber data sekunder adalah berasal dari dokumen resmi (official document) baik berupa hasil penelitian, jurnal, laporan tahunan ataupun laporan kajian terkait pengelolaan IKH baik dalam bentuk softcopy maupun dalam bentuk hardcopy yang diperoleh dari IKH ataupun instansi terkait lainnya.

Sampai saat ini belum ada penelitian
yang melakukan analisis tentang
keberlanjutan pengelolaan limbah di IKH.
Penelitian yang pernah dilakukan terbatas
pada evaluasi keberlanjutan pada peternakan
sapi potong di Desa Wonosobo dengan
menggunakan 5 dimensi keberlanjutan yaitu
ekologi, ekonomi, sosial, teknologi dan
kelembagaan. Akan tetapi belum dilakukan
terhadap aspek kesehatan veteriner. Aspek
kesehatan masyarakat veteriner merupakan
salah satu atribut yang dapat mempengaruhi
keberlanjutan sektor peternakan (Pelletier \&
Tyedmers, 2010).

Berdasarkan aspek-aspek yang telah disampaikan tersebut di atas, selanjutnya hasil akan dijabarkan dalam atribut indikator meliputi 1) Dimensi ekologi yang merupakan penggambaran keberlanjutan fungsi-fungsi ekologis disekitar IKH, yang meliputi; kualitas air permukaan, air tanah, udara, tata ruang (Balkema, Preisig, Otterpohl, Lambert, \& Weijers, 2002), 2) Dimensi ekonomi yang merupakan jaminan kemajuan ekonomi dan mendorong efisiensi, yang digambarkan dari indikator-indikator ekonomi keberadaan IKH, meliputi; dampak terhadap kesejahteraan masyarakat sekitar, potensi nilai ekonomi limbah IKH, hingga alokasi biaya untuk program Corporate Social
Responsibility (CSR) (Flores, Buckley, \& Fenner, 2009), 3) Dimensi sosial merupakan penggambaran interaksi, hubungan satu sama lain (interelasi) dan ketergantungan satu sama lain (interpendensi) dengan masyarakat sekitar, meliputi; tingkat pemahaman masyarakat terhadap IKH, peran serta masyarakat, pengaruh keberadaan IKH terhadap nilai-nilai budaya hingga identifikasi konflik yang muncul dari aktivitas IKH (Werner, 2009), 4) Pemilihan teknologi merupakan penggambaran aplikasi teknologi tepat guna dan ramah lingkungan serta memiliki nilai produktivitas yang tinggi. Dimensi ini digambarkan melalui ketersediaan kelengkapan dan sarana prasarana, aplikasi teknologi dalam opersionalisasi IKH hingga aplikasi teknologi pengelolaan limbah IKH (Gaulke, Weiyang, Scanlon, Henck, \& Hinckley, 2010), 5) Dimensi kelembagaan merupakan penggambaran dukungan aspek-aspek kelembagaan meliputi; ketersediaan hukum dan peraturan, ketersediaan Prosedur Operasional Baku (POB), komitmen kelembagaan, komitmen, pengawasan dan tingkat koordinasi pemerintah hingga kemitraan yang terbentuk (Nhapi \& Gijzen, 2005).

$\begin{array}{llr}\text { Metode } & \text { yang digunakan dalam } \\ \text { melakukan } & \text { analisis } & \text { keberlanjutan }\end{array}$ pengelolaan limbah IKH adalah dengan pendekatan multidimensional scaling (MDS) dengan teknik Rap-AQI (Rapid AppraisalAnimal Quarantine Installation) (Kavanagh \& Pitcher, 2004). Teknik yang digunakan dalam metode MDS ini adalah teknik analisis statistik berbasis komputer dengan menggunakan program Ms Excel yang melakukan transformasi terhadap setiap aspek dan multidimensi keberlanjutan terhadap pengelolaan limbah IKH.

Seluruh data dari atribut yang dipertimbangkan dalam penelitian ini selanjutnya dianalisis secara multidimensi untuk menentukan titik yang mencerminkan posisi keberlanjutan yaitu titik "baik" (good) dan titik "buruk" (bad). Menurut Fauzi dan Anna (2005), MDS pada Rapfish diterapkan dengan menghitung jarak terdekat dari euclidean distance pada persamaan berikut:

$d_{12}=\sqrt{\left(\mathrm{x}_{1}-\mathrm{x}_{2}\right)^{2}+\left(\mathrm{y}_{1}-\mathrm{y}_{2}\right)+\ldots}$ 
Euclidean distance multidimensi antara dua titik tersebut $\left(\mathrm{d}_{12}\right)$ kemudian diproyeksikan ke dalam euclidean distance dua aspek (D12) berdasarkan rumus regresi pada persamaan berikut:

$d_{12}=a+b \mathrm{D}_{12}+e$; dimana $e$ adalah error

Regresi tersebut menerapkan algoritma alscal dengan proses iterasi atau pengulangan untuk mendapat nilai error terkecil. Menurut Kavanagh (2001) algoritma alscal yang diterapkan memaksa nilai intercept pada persamaan diatas bernilai nol sehingga persamaan regresi berubah menjadi persamaan berikut:

$d_{12}=b \mathrm{D}_{12}+e$; dimana $e$ adalah error

Dua titik atau objek yang sama dalam MDS dipetakan dalam satu titik yang saling berdekatan. Objek atau titik yang tidak sama digambarkan dengan titik-titik yang berjauhan. Titik-titik ini berguna didalam analisis regresi untuk menghitung stress yang merupakan bagian dari metode MDS. Nilai pada setiap atribut akan membentuk matriks $\mathrm{X}(\mathrm{n} \times \mathrm{p})$, dimana $\mathrm{n}$ adalah jumlah wilayah beserta titik-titik acuannya, sementara $p$ adalah jumlah atribut yang digunakan.
Standarisasi nilai skor untuk setiap atribut ditetapkan sehingga setiap atribut mempunyai bobot yang seragam dan perbedaan antar skala pengukuran dapat dihilangkan.

Nilai stress merupakan akar kuadrat nilai stress sehingga nilai stress juga bisa diperoleh dengan rumus berikut:

Strees $=\frac{M S S e_{i j k}}{M S S d_{i j k}}$, dimana MSS adalah mean sum square

Proses iterasi dihentikan jika nilai stress kurang dari 0.25 (Fauzi \& Anna, 2013), sebagaimana dirumuskan dalam persamaan berikut:

$$
\text { Stress }=\sqrt{\frac{l}{m} \sum_{k-1}^{m}\left[\frac{\sum_{i} \sum_{j}\left(D_{i j k}-d_{i j k}\right)^{2}}{\sum_{i} \sum_{j} d_{i j k}^{2}}\right]}
$$

Model yang baik ditunjukkan dengan nilai Stress kurang dari 0.25 dan R2 mendekati 1. Skala indeks keberlanjutan memiliki rentang 0-100. Sehingga penggambaran keberlanjutan IKH ditetapkan dalam 4 kategori status keberlanjutan seperti seperti berikut:

\begin{tabular}{ll}
\hline Nilai Indeks & Kategori \\
\hline $0-25$ & Buruk (Tidak Berkelanjutan) \\
$25-50$ & Kurang (Kurang Berkelanjutan) \\
$51-74$ & Cukup (Cukup Berkelanjutan) \\
$75-100$ & Baik (Berkelanjutan) \\
\hline
\end{tabular}

Sumber: (Kavanagh \& Pitcher, 2004)

Hasil lain yang analisis dalam MDS adalah faktor pengungkit atau leverage analysis yang merupakan faktor strategis dalam kegiatan pengelolaan di masa depan. Leverage analysis bertujuan melihat kesalahan/ error dalam penentuan nilai keberlanjutan jika diputuskan salah satu atribut dikeluarkan dari analisis. Menurut Pitcher (1999), leverage analysis atau analisis sensitivitas dilakukan terhadap seluruh atribut dari masing-masing aspek. Perhitungan dilakukan dengan metode stepwise, yaitu membuang setiap atribut secara berurutan satu persatu kemudian menghitung nilai error atau root mean square (RMS), dibandingkan dengan nilai RMS yang dihasilkan pada saat seluruh atribut dianalisis. Metode ini dikenal sebagai metode jackknife (Kavanagh \& Pitcher, 2004). Evaluasi pengaruh error pada proses pendugaan nilai ordinasi analisis status keberlanjutan dilakukan dengan menggunakan analisis Monte Carlo.

Penelitian ini menggunakan metoda MDS dengan Rap-AQI yang merupakan modifikasi dari Rapfish hasil pengembangan University of Columbia untuk menilai keberlanjutan perikanan laut. Analisis 
ordinasi Rap-AQI ini dilakukan melalui tahapan yaitu: (1) penentuan atribut, (2) penilaian setiap atribut dalam skala ordinal, (3) analisis ordinasi Rap-AQI dengan metoda MDS menggunakan excel untuk menentukan ordinasi dan nilai stress; (4) menilai indeks dan status keberlanjutan pengelolaan limbah IKH, (5) leverage analysis untuk menentukan peubah yang sensitif mempengaruhi keberlanjutan pengelolaan limbah di IKH, dimana yang akan dijadikan atribut dominan adalah atribut yang berada diatas rata-rata dan (6) Analisis Monte Carlo untuk memperhitungkan aspek ketidak pastiannya (Pitcher et al., 2013).

\section{HASIL}

Pada Tabel 1 dapat dilihat frekuensi penggunaan IKH PT. Legok makmur Lestari dan IKH SKP KLS 1 CILACAP sejak tahun 2013 sampai dengan 2017. Sejak tahun 2013 sampai dengan 2017 IKH PT. Legok makmur Lestari melakukan karantina sebanyak 137.626 ekor ruminansia dan melakukan impor sebanyak 76 kali. Sedangkan IKH SKP KLS 1 Cilacap melakukan karantina 112.773 ekor ruminansia dan melakukan impor sebanyak 60 kali.

Tingginya aktifitas IKH ini akan menghasilkan volume limbah yang banyak. Limbah padat yang dihasilkan setiap pagi dikumpukan dan ditampung pada satu tempat, limbah padat tersebut dapat digunakan oleh masyarakat secara langsung tanpa diolah, baik digunakan sendiri ataupun di jual. Sedangkan limbah cair yang dihasilkan dialirkan melalui saluran khusus yang pada akhirnya bermuara pada kolam penampungan. Kolam penampungan yang dibuat terdiri dari empat tingkat dengan tujuan agar limbah cair yang dihasilkan dari sisa urine dan air sisa pembersihan kandang dapat terencerkan.

Tabel 1. Penggunaan IKH PT Legok Makmur Lestari dan IKH SKP Kelas 1 Cilacap tahun 2013-2017 berdasarkan jumlah dan frekuensi impor ruminansia besar

\begin{tabular}{llrrrr}
\hline & \multirow{2}{*}{ TAHUN } & \multicolumn{2}{l}{ IKH PT Legok Makmur Lestari } & \multicolumn{3}{l}{ IKH SKP Kelas 1 Cilacap } \\
\cline { 3 - 6 } & \multicolumn{2}{c}{ Jumlah (ekor) } & Frekuensi (kali) & Jumlah (ekor) & Frekuensi (kali) \\
\hline 1 & 2013 & 14.976 & 11 & 18,946 & 11 \\
2 & 2014 & 39.332 & 23 & 20,646 & 13 \\
3 & 2015 & 25.228 & 12 & 27,197 & 14 \\
4 & 2016 & 25.760 & 13 & 21,910 & 12 \\
5 & 2017 & 32.350 & 17 & 24,074 & 10 \\
\hline \multicolumn{2}{l}{ TOTAL } & 137.626 & 76 & 112.773 & 60 \\
\hline
\end{tabular}

Hasil pengujian air limbah IKH dan badan air permukaan menunjukkan, parameter umum pencemaran dari air limbah IKH yaitu total solid suspention (TSS), chemical oxygen demand (COD), biological oxygen demand (BOD), amoniak, total bakteri Coliform dan Escherichia coli melebihi baku mutu air limbah peternakan sapi, demikian juga dengan sampel badan air permukaan yg ada disekitar IKH melebihi baku mutu yang ditetapkan pemerintah (Zainudin, 2019).
Berdasarkan hasil analisis Rap-IKH terlihat bahwa indeks keberlanjutan pengelolaan limbah di IKH penilaian atribut yang mencakup 5 aspek keberlanjutan menghasilkan stress analisis MDS masingmasing aspek (ekologi, ekonomi, sosial, teknologi dan kelembagaan) menunjukkan nilai rerata kurang dari 0,25 , sedangkan koefisien determinasi (R2) pada setiap aspek reratanya mendekati 1 (Tabel 2). Berdasarkan kedua parameter statistik tersebut dapat dikatakan bahwa seluruh atribut yang digunakan pada setiap aspek mampu 
menggambarkan keberlanjutan pengelolaan limbah di IKH.

Tabel 2. Parameter statistik aspek keberlanjutan meliputi ekologi, ekonomi,sosial, teknologi dan kelembagaan

\begin{tabular}{lrrrrr}
\hline \multirow{2}{*}{ Parameter } & \multicolumn{5}{c}{ Aspek Keberlanjutan } \\
\cline { 2 - 6 } \multicolumn{1}{c}{ Stress } & Ekologi & \multicolumn{1}{c}{ Ekonomi } & \multicolumn{1}{c}{ Sosial } & Teknologi & Kelembagaan \\
R2 & 0,13 & 0,14 & 0,16 & 0,14 & 0,15 \\
\hline
\end{tabular}

$\begin{array}{lll}\text { Keberlanjutan ekologi adalah } & \text { juga dapat terjadi. Berdasarkan parameter } \\ \text { gambaran keberlanjutan fungsi-fungsi } & \begin{array}{l}\text { ekologis yang terkait dengan pengelolaan } \\ \text { ekologis yang berada di sekitar IKH. }\end{array} \text { limbah IKH, diperoleh hasil analisis } \\ \text { Keberadaan IKH dan limbah yang dihasilkan } & \text { keberlanjutan dimensi ekologi seperti terlihat } \\ \text { berpotensi mencemari lingkungan sekitar, } & \text { pada Gambar 1. Hasil analisis RapIKH } \\ \text { seperti pencemaran air tanah dan air } & \text { menunjukkan bahwa nilai keberlanjutan } \\ \text { permukaan yang terjadi karena resapan dan } & \text { ekologi yang diperoleh IKH Pemerintah } \\ \text { limpasan dari limbah kotoran ternak. } & \text { (IKHP) adalah 49,24\% dan IKH Swasta } \\ \text { Penceman udara berupa debu dan } & \text { (IKHS) adalah 54,17\% (Gambar 1). }\end{array}$
kebisingan yang ditimbulkan suara ternak

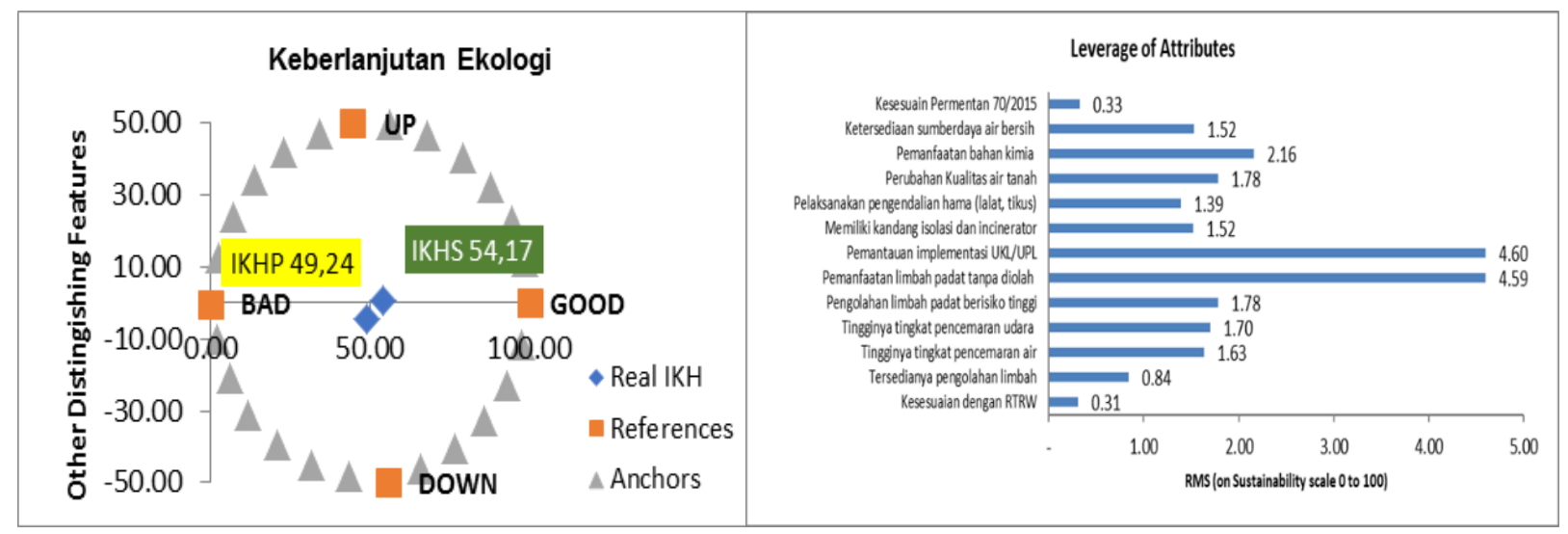

Gambar 1. Keberlanjutan ekologi pengelolaan limbah IKH

Indikator utama ekonomi adalah pertumbuhan ekonomi yang diukur berdasarkan indikator-indikator mikro seperti pendapatan, efisiensi dan pengeluaran atau biaya. Berdasarkan parameter ekonomi yang terkait dengan pengelolaan limbah $\mathrm{IKH}$, diperoleh hasil analisis keberlanjutan dimensi ekonomi seperti tampak pada Gambar 2. Hasil analisis RapIKH menunjukkan bahwa nilai keberlanjutan ekonomi diperoleh IKH Pemerintah (IKHP) sebesar 47,65\% dan IKH Swasta (IKHS) sebesar 65,72\% (Gambar 2) 


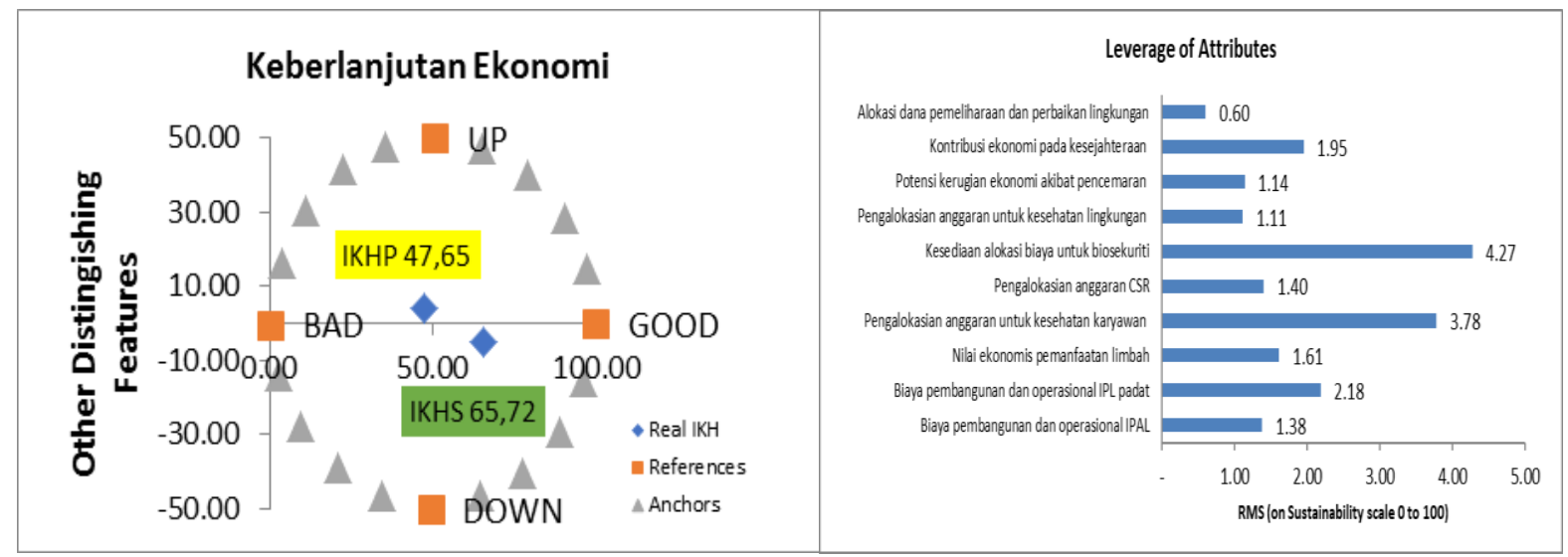

Gambar 2. Keberlanjutan ekonomi pengelolaan limbah IKH

Keberlanjutan sosial merupakan gambaran keberlanjutan aspek-aspek sosial dalam pengelolaan IKH. Salah satu indikator utama aspek sosial adalah pemerataan pendapatan masyarakat sekitar yang dapat diukur. Semakin besar manfaat dan akan semakin banyak masyarakat yang merasakan diuntungkan dengan kehadiran IKH, maka kegiatan IKH tersebut akan semakin berlanjut. Indikator tingkat penerimaan yang lain adalah banyaknya komplain atau protes dan juga munculnya konflik antara kegiatan
IKH dengan masyarakat. Semakin tinggi tingkat penerimaan maka semakin rendah konflik yang dapat terjadi. Berdasarkan parameter-parameter sosial yang terkait dengan pengelolaan limbah IKH, diperoleh hasil analisis keberlanjutan dimensi sosial seperti terlihat pada Gambar 3. Hasil analisis RapIKH menunjukkan bahwa nilai keberlanjutan sosial diperoleh IKH Pemerintah (IKHP) sebesar 55,77\% dan IKH Swasta (IKHS) sebesar 57,47\% (Gambar 3).

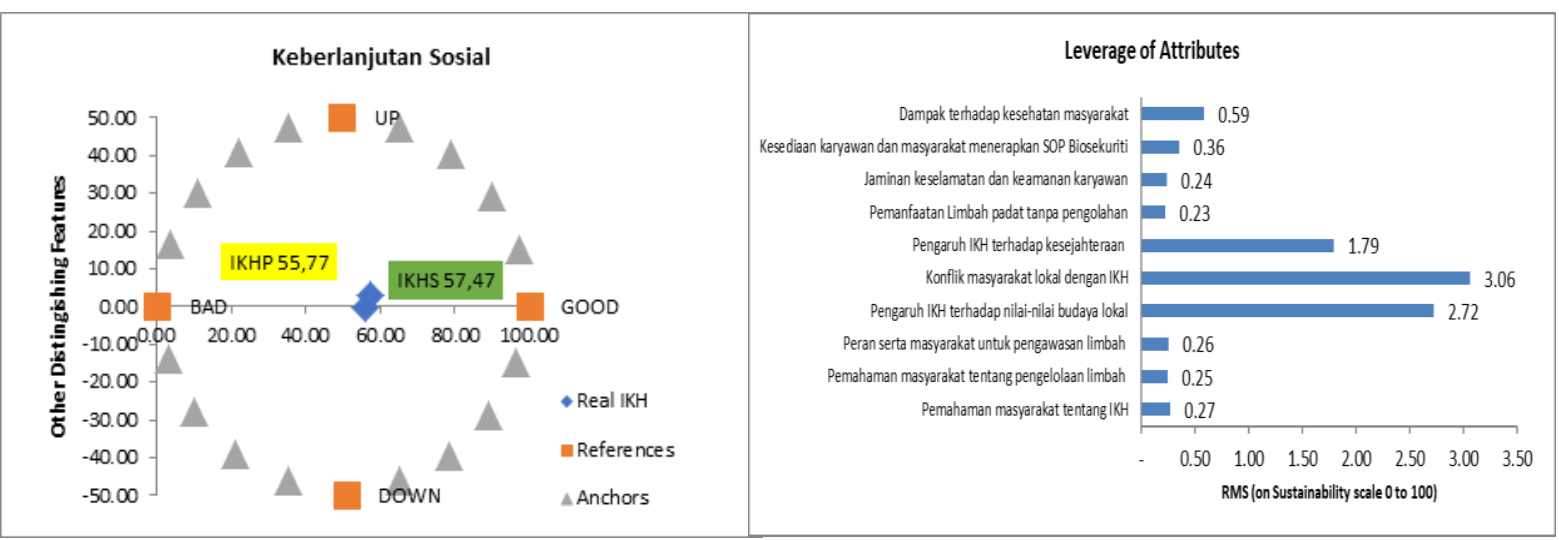

Gambar 3 Keberlanjutan sosial pengelolaan limbah IKH

Efektivitas dan efisiensi dalam pengelolaan limbah IKH tergambar dalam keberlanjutan teknologi. Indikator utama keberlanjutan teknologi adalah aplikasi teknologi tepat guna dan ramah lingkungan. Indikator tersebut diharapkan dapat meningkatkan efektivitas dan efisiensi dalam pengoperasiannya. Pada Gambar 4 dapat dilihat hasil analisis keberlanjutan dimensi teknologi berdasarkan parameter-parameter teknologi yang terkait dengan pengelolaan limbah IKH. Hasil analisis RapIKH menunjukkan bahwa nilai keberlanjutan teknologi diperoleh IKH Pemerintah (IKHP) sebesar 29,27\% dan IKH Swasta (IKHS) sebesar 54,89\% (Gambar 4). 


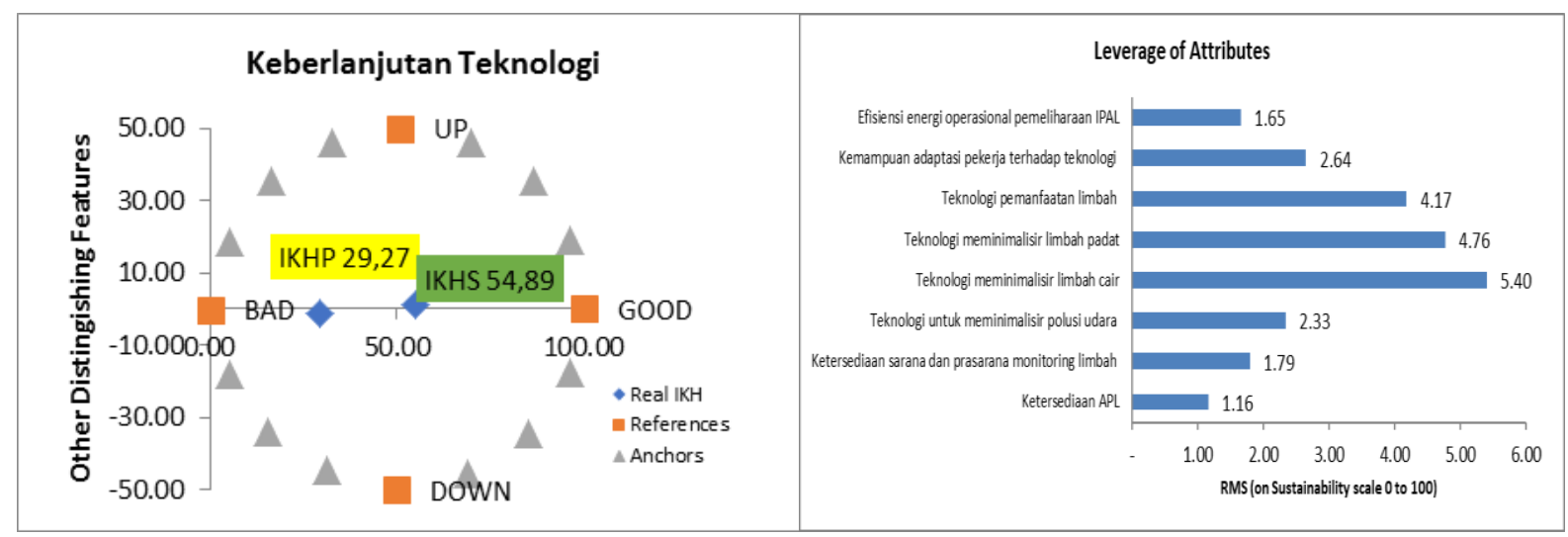

Gambar 4. Keberlanjutan teknologi pengelolaan limbah IKH

Keberlanjutan kelembagaan merupakan gambaran keberlanjutan aspek hukum dan peraturan serta keorganisasi dalam pengelolaan IKH. Indikator utama dimensi kelembagaan adalah keorganisasi, hukum dan peraturan. Menurut Djogo et al. (2003) kelembagaan umumnya ditekankan pada aturan main dan kegiatan kolektif untuk kepentingan bersama. Lebih jauh disebutkan bahwa kelembagaan berisikan dua aspek penting yakni; aspek kelembagaan dan aspek keorganisasian. Aspek kelembagaan meliputi perilaku yang terdiri dari nilai (value), norma (norm), custom, mores, folkways, usage, kepercayaan, gagasan, doktrin, keinginan, kebutuhan, orientasi dan lain-lain. Sementara aspek keorganisasian meliputi struktur atau peran yang terdiri dari peran, aktivitas, hubungan antar peran, integrasi sosial, struktur umum, perbandingan struktur tekstural dengan struktur faktual, struktur kewenangan atau kekuasaan, hubungan antar kegiatan dengan tujuan yang hendak dicapai, aspek solidaritas, klik, profil dan pola kekuasaan. Pada Gambar 5 terlihat hasil analisis keberlanjutan dimensi kelembagaan berdasarkan parameter-parameter kelembagaan yang terkait dengan pengelolaan limbah IKH. Hasil analisis RapIKH menunjukkan bahwa nilai keberlanjutan kelembagaan diperoleh IKH Pemerintah (IKHP) sebesar 43,53\% dan IKH Swasta (IKHS) sebesar 50,73\% (Gambar 5).
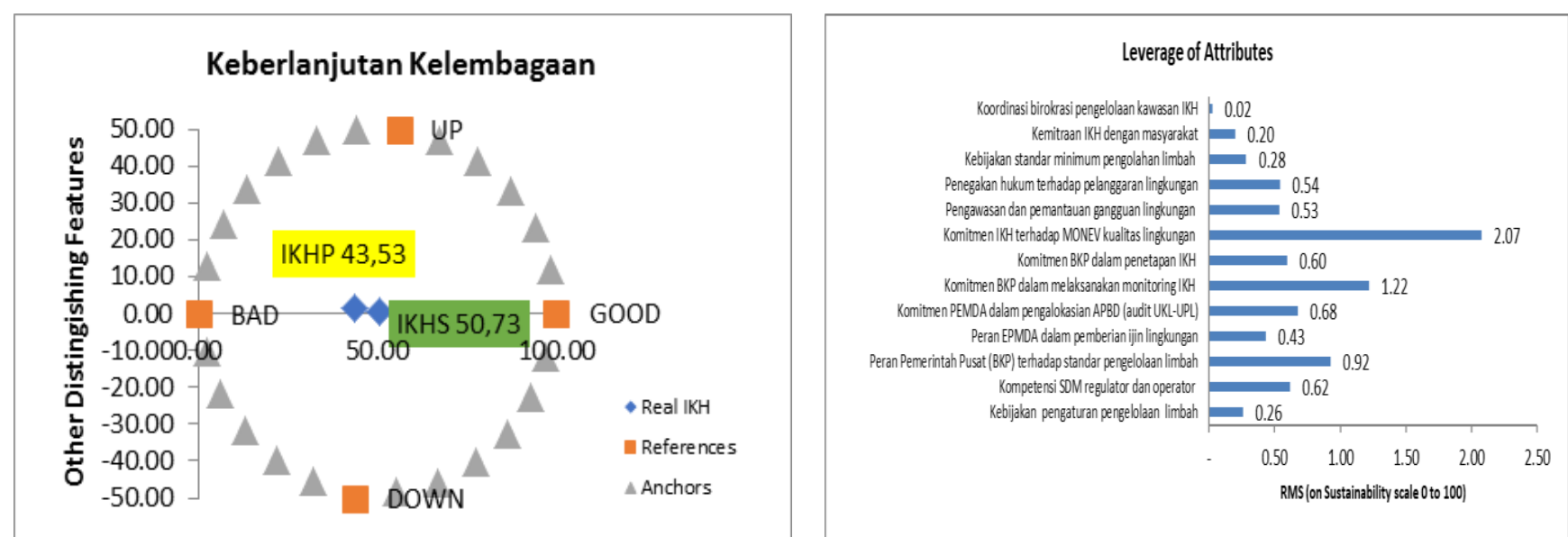

Gambar 5 Keberlanjutan kelembagaan pengelolaan limbah IKH

Berdasarkan hasil analisis leverage RapIKH, terdapat 12 faktor kunci keberlanjutan IKH yaitu teknologi pemanfaatan limbah IKH, komitmen pemilik IKH terhadap monitoring dan evaluasi kualitas lingkungan yang tercantum dalam UKL/UPL, komitmen Badan Karantina Pertanian dalam melaksanakan monitoring IKH (aspek pengelolaan limbah), IKH melaksanakan UKL/UPL setiap 6 bulan 
sekali dengan target pemantauan sesuai dengan peraturan yang berlaku, pengalokasian anggaran untuk pencegahan terjadinya gangguan kesehatan kepada karyawa, teknologi untuk meminimalisir risiko limbah padat dan teknologi untuk meminimalisir polusi limbah cair. Pada Tabel 4 dapat dilihat perbandingan indeks keberlanjutan masing-masing dimensi pada IKH pemerintah (IKHP) dan IKH swasta (IKHS). Status keberlanjutan IKHP menunjukkan 1 dari 5 dimensi parameter (20\%) menunjukkan status cukup yaitu dimensi sosial, sedangkan pada IKHS semua dimensi keberlanjutan menunjukkan status cukup (100\%) Tabel 3).

Tabel 4 . Perbandingan indeks dan status keberlanjutan IKHP dan IKHS

\begin{tabular}{|c|c|c|c|c|c|c|c|c|}
\hline \multirow{3}{*}{$\begin{array}{c}\text { Dimensi } \\
\text { Keberlanjutan }\end{array}$} & \multicolumn{8}{|c|}{ Indeks Keberlanjutan } \\
\hline & \multicolumn{4}{|c|}{ IKH Pemerintah } & \multicolumn{4}{|c|}{ IKH Pihak lain } \\
\hline & MDS & $\begin{array}{l}\text { Monte } \\
\text { Carlo }\end{array}$ & Selisih & $\begin{array}{c}\text { Status } \\
\text { Keberlanjutan }\end{array}$ & MDS & $\begin{array}{l}\text { Monte } \\
\text { Carlo }\end{array}$ & Selisih & $\begin{array}{c}\text { Status } \\
\text { Keberlanjutan }\end{array}$ \\
\hline Ekologi & 49,24 & 49,16 & $0,07(0,4 \%)$ & Kurang & 54,17 & 54,29 & $0,41(0,22 \%)$ & Cukup \\
\hline Ekonomi & 45,30 & 45,26 & $0,04(0,08 \%$ & Kurang & 70,12 & 69,21 & $0,91(1,29 \%)$ & Cukup \\
\hline Sosial & 55,77 & 55,30 & $0,46(0,82 \%)$ & Cukup & 57,47 & 57,21 & $026(0,45 \%)$ & Cukup \\
\hline Teknologi & 29,27 & 30,32 & $1,05(3,50 \%)$ & Kurang & 54,89 & 54,43 & $0,45(0,83 \%)$ & Cukup \\
\hline Kelembagaan & 43,53 & 45,50 & $0,02(0,04 \%)$ & Kurang & 50,73 & 50,70 & $0,01(0,02 \%)$ & Cukup \\
\hline Multidimensi & 45,02 & 45,10 & $0.40(0.27 \%)$ & Kurang & 57,47 & 57,16 & $0,50(0,56 \%)$ & Cukup \\
\hline
\end{tabular}

Trade off keberlanjutan pengelolaan limbah IKH merupakan gambaran grafis kondisi dari keberlanjutan pengelolaan limbah IKH yang meliputi dimensi ekologi, ekonomi, sosial, teknologi dan kelembagaan. Gambar 6 menunjukkan elemen-elemen penentu keberlanjutan. Untuk melihat keberlanjutan dimensi pengelolaan secara menyeluruh maka dapat digambarkan dalam diagram yang menggambarkan trade off antara dimensi pengelolaan. Kondisi trade off keberlanjutan pengelolaan limbah IKH menunjukkan bahwa tingkat pengelolaan IKH swasta tergolong lebih baik dibanding IKH Pemerintah. Hal tersebut tampak dari nilai rata-rata $\mathrm{IKH}$ swasta $(56,60 \%)$ lebih tinggi dibandingkan IKH Pemerintah $(45,09 \%)$. Kondisi per dimensi juga tampak bahwa dimensi teknologi merupakan dimensi pengelolaan yang mengalami nilai keberlanjutan terendah.

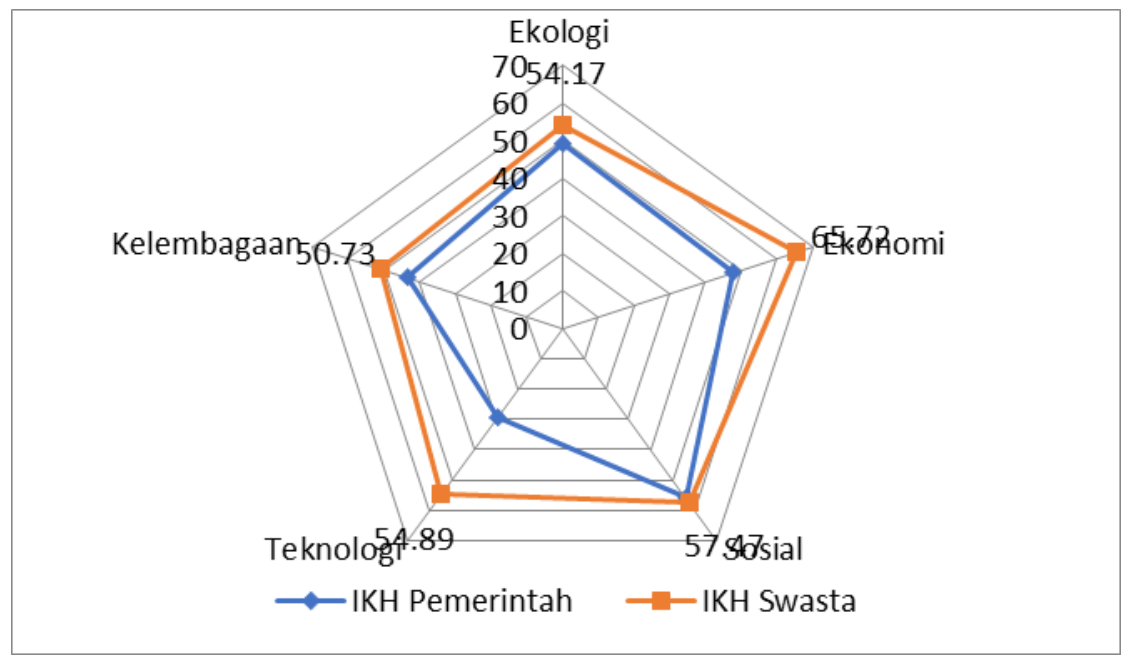

Gambar 6. Trade off keberlanjutan pengelolaan limbah IKH 


\section{PEMBAHASAN}

Nilai indeks $>50 \%$ dapat dinyatakan bahwa aspek yang dikaji bisa berkelanjutan dan sebaliknya jika nilai indeks $<50 \%$ maka aspek tersebut dinyatakan belum atau tidak bisa berkelanjutan. Hasil ini menunjukkan bahwa dari aspek ekologi, pengelolaan limbah pada IKH Swasta tergolong cukup baik bila dibandingkan dengan pengelolaan limbah di IKH Pemerintah (Pitcher et al., 2013). Salah satu perbedaan antara manajemen swasta dan manajemen pemerintah adalah standar ukuran keberhasilan. Standar dan ukuran keberhasilan dari manajemen pemerintah lebih kabur atau sulit disepakati dibanding standar atau ukuran untuk menilai keberhasilan manajemen swasta (Allison, 1969). Sektor pemerintah lebih rentan terhadap intervensi atau pengaruh dari berbagai kelompok kepentingan dalam mengambil suatu kebijakan, sehingga seringkali mengganggu rasionalitas dan efektifitas dari kebijakan yang diambil. Kondisi tersebut akan berdampak terhadap tingkat efektivitas pengelolaan limbah IKH. Adanya pencemaran air akibat aktifitas IKH juga telah dibuktikan (Perry., Hondeghem \& Wise, 2010).

Berdasarkan hasil analisis leverage RapIKH, terdapat 2 atribut pengungkit keberlanjutan dimensi ekologi yang memiliki sensitivitas paling tinggi yakni; a) IKH melaksanakan pemantauan implementasi UKL/UPL setiap 6 bulan sekali dengan target pemantauan sesuai dengan peraturan yang berlaku, dan b) Pemanfaatan limbah padat IKH oleh masyarakat/pekerja tanpa diolah terlebih dahulu. Kedua atribut tersebut menunjukkan nilai RMS yang relatif lebih tinggi dibandingkan dengan nilai RMS atribut lainnya. Nilai RMS menunjukkan besarnya peranan setiap atribut terhadap sensitivitas status keberlanjutan (Kavanagh \& Pitcher, 2004). Lebih jauh Yusuf (2017) bahwa atribut pengungkit merupakan atribut yang memiliki nilai dominan (extreme bar) atau nilai lebih dari setegah nilai tertinggi (Yusuf, 2016).

Pada aspek ekonomi terjadi kondisi yang kurang lebih sama dengan pengelolaan IKH pada aspek ekologi. Pengelolaan limbah pada IKH Swasta tergolong cukup baik bila dibandingkan dengan pengelolaan limbah di IKH Pemerintah. Salah satu perbedaan antara manajemen swasta dan manajemen publik adalah tekanan pelayanan. Di organisasi swasta cenderung menenkankan aspek pencapaian efisiensi organisasi, yang diwakili penghitungan untung rugi. Sementara itu organisasi publik (pemerintah) lebih menekankan pada pemerataan atau keadilan (Allison, 1969). Selain itu, sektor publik (pemerintah) lebih rentan terhadap intervensi atau pengaruh dari berbagai kelompok kepentingan dalam mengambil suatu kebijakan, sehingga seringkali mengganggu rasionalitas dan efektifitas dari kebijakan yang diambil. Kondisi ini akan berdampak terhadap tingkat efektivitas pengelolaan limbah IKH (Perry et al., 2010).

Hasil analisis leverage RapIKH memperoleh 2 atribut pengungkit keberlanjutan dimensi ekonomi yang memiliki sensitivitas paling tinggi yakni; a) Kesediaan IKH dalam mengalokasikan biaya untuk menerapkan prinsip biosekuriti, dan b) Pengalokasian anggaran untuk pencegahan terjadinya gangguan kesehatan kepada karyawan. Kedua atribut tersebut menunjukkan nilai RMS yang relatif lebih tinggi dibandingkan dengan nilai RMS atribut lainnya. Kavanagh dan Pitcher (2004) menyatakan bahwa nilai RMS menunjukkan besarnya peranan setiap atribut terhadap sensitivitas status keberlanjutan

Tingkat pengelolaan kedua IKH Pemerintah dan Swasta tergolong berkelanjutan atau dikategorikan cukup berkelanjutan. Meskipun nilai keberlanjutan IKH Swasta lebih tinggi dibanding nilai keberlanjutan IKH Pemerintah namun kedua IKH menunjukkan bahwa dari aspek sosial terjadi kondisi pengelolaan yang kurang lebih sama. Hal ini cukup berbeda dengan aspek ekologi dan aspek ekonomi. Perbedaan nilai yang tidak signifikan tersebut dapat disebabkan faktor manajerial, dimana pada sektor swasta umumnya lebih simple dengan tujuan mengejar keuntungan, sedangkan pada sektor publik, umumnya bersifat protokeler dan berorientasi pada pemerataan. Salah satu perbedaan antara manajemen swasta dan manajemen publik adalah tekanan pelayanan. Di organisasi swasta cenderung menenkankan aspek pencapaian efisiensi 
organisasi, yang diwakili penghitungan untung rugi. Sementara itu organisasi publik (pemerintah) lebih menekankan pada pemerataan atau keadilan (Allison, 1969). Selain itu sektor publik (pemerintah) lebih rentan terhadap intervensi atau pengaruh dari berbagai kelompok kepentingan dalam mengambil suatu kebijakan, sehingga seringkali mengganggu rasionalitas dan efektifitas dari kebijakan yang diambil. Kondisi ini akan berdampak terhadap tingkat efektivitas pengelolaan limbah IKH (Perry et al., 2010).

Pada analisis leverage RapIKH, diperoleh bahwa terdapat atribut pengungkit keberlanjutan dimensi sosial yang memiliki sensitivitas paling tinggi yakni; a) Konflik masyarakat lokal dengan IKH, b) Pengaruh keberadaan IKH terhadap nilai-nilai budaya lokal, dan c) Pengaruh IKH terhadap kesejahteraan masyarakat. Ketiga atribut tersebut menunjukkan nilai RMS yang relatif lebih tinggi dibandingkan dengan nilai RMS atribut lainnya.

Pada aspek teknologi terjadi kondisi yang kurang lebih sama dengan pengelolaan IKH pada aspek ekologi dan ekonomi. Pengelolaan limbah pada IKH Swasta tergolong cukup baik bila dibandingkan dengan pengelolaan limbah di IKH Pemerintah. Salah satu perbedaan antara manajemen swasta dan manajemen publik adalah tekanan pelayanan. Di organisasi swasta cenderung menekankan aspek pencapaian efisiensi organisasi, yang diwakili penghitungan untung rugi (Allison, 1969). Sementara itu organisasi publik (pemerintah) lebih menekankan pada pemerataan atau keadilan. Sektor publik (pemerintah) lebih rentan terhadap intervensi atau pengaruh dari berbagai kelompok kepentingan dalam mengambil suatu kebijakan, sehingga seringkali mengganggu rasionalitas dan efektifitas dari kebijakan yang diambil. Kondisi ini akan berdampak terhadap tingkat efektivitas pengelolaan limbah IKH (Perry et al., 2010).

Berdasarkan hasil analisis leverage $R a p-I K H$, terdapat 3 atribut pengungkit keberlanjutan dimensi teknologi yang memiliki sensitivitas paling tinggi yakni; a) Teknologi untuk meminimalisir polusi limbah cair, b) Teknologi untuk meminimalisir risiko limbah padat, dan c) Teknologi pemanfaatan limbah IKH. Ketiga atribut tersebut menunjukkan nilai RMS yang relatif lebih tinggi dibandingkan dengan nilai RMS atribut lainnya. Nilai RMS menunjukkan besarnya peranan setiap atribut terhadap sensitivitas status keberlanjutan (Kavanagh \& Pitcher, 2004).

Pada aspek kelembagaan terjadi kondisi yang kurang lebih sama dengan pengelolaan IKH pada aspek ekologi, ekonomi, dan teknologi. Pengelolaan limbah pada IKH Swasta tergolong cukup baik bila dibandingkan dengan pengelolaan limbah di IKH Pemerintah. Salah satu perbedaan antara manajemen swasta dan manajemen publik adalah tekanan pelayanan standar ukuran keberhasilan. Di organisasi swasta cenderung menenkankan aspek pencapaian efisiensi organisasi, yang diwakili penghitungan untung rugi. Sementara itu organisasi publik (pemerintah) lebih menekankan pada pemerataan atau keadilan (Allison, 1969). Sektor publik (pemerintah) lebih rentan terhadap intervensi atau pengaruh dari berbagai kelompok kepentingan dalam mengambil suatu kebijakan, sehingga seringkali mengganggu rasionalitas dan efektifitas dari kebijakan yang diambil. Kondisi ini akan berdampak terhadap tingkat efektivitas pengelolaan limbah IKH (Perry $e t$ al., 2010).

Terdapat 2 atribut pengungkit keberlanjutan dimensi kelembagaan yang memiliki sensitivitas paling tinggi yakni; a) Komitmen pemilik IKH terhadap monitoring dan evaluasi kualitas lingkungan yang tercantum dalam UKL-UPL, dan b) Komitmen Badan Karantina Pertanian dalam penetapan IKH yang sesuai dengan peraturan yang berlaku. Kedua atribut tersebut menunjukkan nilai RMS yang relatif lebih tinggi dibandingkan dengan nilai RMS atribut lainnya. Nilai RMS menunjukkan besarnya peranan setiap atribut terhadap sensitivitas status keberlanjutan (Kavanagh \& Pitcher, 2004). Lebih jauh, atribut pengungkit merupakan atribut yang memiliki nilai dominan (extreme bar) atau nilai lebih dari setegah nilai tertinggi (Yusuf, 2016).

Yusuf (2016) mengemukakan bahwa untuk melihat keberlanjutan dimensi pengelolaan secara menyeluruh maka dapat 
digambarkan dalam bentuk kite diagram yang merupakan penggambaran trade off antara dimensi pengelolaan. Kondisi trade off keberlanjutan pengelolaan limbah IKH menunjukkan bahwa tingkat pengelolaan IKH swasta tergolong lebih baik dibanding IKH Pemerintah. Hal tersebut tampak dari nilai rata-rata $\mathrm{IKH}$ swasta $(56,60 \%)$ lebih tinggi dibandingkan IKH Pemerintah $(45,09 \%)$. Kondisi per dimensi juga tampak bahwa dimensi teknologi merupakan dimensi pengelolaan yang mengalami nilai keberlanjutan terendah (Yusuf, 2016).

\section{KESIMPULAN}

Pada tingkat pengelolaan limbah IKH setiap dimensi dari 5 dimensi, dimensi teknologi pada IKH pemerintah memiliki tingkat keberlanjutan terendah (kurang berlanjut) dan dimensi sosial mempunyai tingkat keberlanjutan tertinggi (cukup berlanjut). Sementara itu, tingkat pengelolaan limbah IKH swasta secara keseluruhan pada kelima dimensi dikategorikan cukup berlanjut. Keberlanjutan atau sustainability terjadi bila semua aspek keberlanjutan terpenuhi (indeks >50\%) yang mencakup ekonomi, sosial, teknologi, kelembagaan, dan ekologi. Tingkat pengelolaan limbah IKH swasta tergolong lebih baik dibandingkan dengan tingkat pengelolaan limbah IKH pemerintah. Terdapat 12 faktor kunci untuk meningkatkan tingkat keberlanjutan pada pengelolaan limbah di IKH yang meliputi 1) pemantauan implementasi UKL/UPL setiap 6 bulan, 2) pemanfaatan limbah padat IKH tanpa diolah terlebih dahulu, 3) kesediaan alokasi biaya untuk biosekuriti, 4) alokasi anggaran untuk kesehatan karyawan, 5) konflik masyarakat lokal dengan IKH, 6) pengaruh $\mathrm{KH}$ terhadap nilai-nilai budaya lokal, dan 7) pengaruh IKH terhadap kesejahteraan masyarakat, 8) teknologi untuk meminimalisir limbah cair, 9) teknologi untuk meminimalisir risiko limbah padat, 10) teknologi pemanfaatan limbah, 11) komitmen pemilik IKH terhadap monitoring dan evaluasi kualitas lingkungan yang tercantum dalam UKL-UPL, dan 12) komitmen Badan Karantina Pertanian dalam penetapan IKH yang sesuai dengan peraturan yang berlaku.

\section{UCAPAN TERIMAKASIH}

Terima kasih kami sampaikan kepada Kepala Badan Karantina Pertanian Kementerian Pertanian dan Program Studi Pengelolaan Sumber Daya Alam dan Lingkungan Institut Pertanian Bogor.

\section{DAFTAR PUSTAKA}

Allison, G. T. (1969). Conceptual Models and The Cuban Missile Crisis. American Political Science Review, 63(3), 689-718. https://doi.org/10.1017/S0003055400276314

Bakeri, S., J. P, M. Y., Riani, E., \& Sutjahjo, S. H. (2012). ANALISIS MDS (MULTI DIMENSIONAL SCALLING) UNTUK KEBERLANJUTAN PENGELOLAAN AIR LINTAS WILAYAH Studi Kasus DKI Jakarta. Jurnal Teknologi Lingkungan, 13(1), 13-23. https://doi.org/10.29122/jtl.v13i1.1401

Balkema, A. J., Preisig, H. A., Otterpohl, R., Lambert, A. J. D., \& Weijers, S. R. (2002). Developing a model based decision support tool for the identification of sustainable treatment options for domestic wastewater. Urban Water, 4, 153-161. https://doi.org/10.2166/wst.2001.0434

Danial, R., Latif, H., \& Indrawati, A. (2015). Deteksi Residu Hormon Trenbolon Asetat pada Sapi Siap Potong Impor asal Australia. Acta VETERINARIA Indonesiana, 3(2), 70-76. https://doi.org/10.29244/avi.3.2.70-76

Fauzi, A., \& Anna, S. (2013). Pemodelan sumber daya perikanan dan kelautan untuk analisis kebijakan. https://doi.org/10.1016/S03044017(96)01152-1

Flores, A., Buckley, C., \& Fenner, R. (2009). Selecting sanitation systems for sustainability in developing countries. 11th International Conference on Urban Drainage, Edinburgh, Scotland, UK, 2008, 1-10. https://doi.org/10.2166/wst.2009.375

Gaulke, L. S., Weiyang, X., Scanlon, A., Henck, A., \& Hinckley, T. (2010). Evaluation criteria for implementation of a sustainable sanitation and wastewater treatment system at Jiuzhaigou National Park, Sichuan Province, China. Environmental Management, 45(1), 93-104. https://doi.org/10.1007/s00267-0099398-1

Hutchison, M. L., Walters, L. D., Avery, S. M., Synge, B. A., \& Moore, A. (2004). Levels of zoonotic agents in British livestock manures. Letters in Applied Microbiology, 39, 207$214 . \quad$ https://doi.org/10.1111/j.1472765X.2004.01564.X

Kavanagh, P., \& Pitcher, T. J. (2004). Implementing Microsoft Excel Software For. Fisheries Centre Research Reports, 12(2), 1-72.

Loisa, Lukman, D. W., \& Latif, H. (2016). Resistensi Salmonella sp. terhadap beberapa antibiotik pada daging itik di Kabupaten Bogor yang 
dapat memengaruhi kesehatan konsumen. Jurnal Kedokteran Hewan, 10(2), 115-120.

Nhapi, I., \& Gijzen, H. J. (2005). A 3-step strategic approach to sustainable wastewater management. Water SA, 31(1), 133-140. https://doi.org/10.4314/wsa.v31i1.5130

Pelletier, N., \& Tyedmers, P. (2010). Forecasting potential global environmental costs of livestock production 2000-2050. Proceedings of the National Academy of Sciences of the United States of America, 107(43), 1837118374.

https://doi.org/10.1073/pnas.1004659107

Peraturan Menteri Lingkungan Hidup No. 1815. (2014). Retrieved from ditjenpp.kemenkumham.go.id/arsip/bn/2014/ bn1815-2014.pdf

Peraturan Pemerintah No. 82. (2000).

Permentan No. 14. https://doi.org/10.5151/cidi2017-060

$\begin{array}{lll}\text { Permentan No. } & 70 .\end{array}$ https://doi.org/10.1590/s180998232013000400007

Perry, J. L., Hondeghem, A., \& Wise, L. R. (2010). Revisiting the Motivational Bases of Public Service: Twenty Years of Research and an Agenda for the Future. 1st Annual Northeast Conference on Public Administration (NECoPA), 8(5), 681-690. https://doi.org/10.3892/ijmm.8.5.549

Pitcher, T. J., Lam, M. E., Ainsworth, C., Martindale, A., Nakamura, K., Perry, R. I., \& Ward, T. (2013). Improvements to Rapfish: A rapid evaluation technique for fisheries integrating ecological and human dimensionsa. Journal of Fish Biology, 83(4), 865-889. https://doi.org/10.1111/jfb.12122

Santoso, G. (2012). Kajian Biosekuriti Instalasi Karnatina Hewan Sapi Impor di Pulau Jawa. Institut Pertanian Bogor.

Serageldin, I. (1996). Sustainability and the wealth of nations: first steps in an ongoing journey. Washington, D.C: Library of Congress Cataloging in Publication Data.

Soemarwoto, O. (2014). Analisis Mengenai Dampak Lingkungan. Yogyakarta: Gadjah Mada University Press.

Werner, M. (2009). Water and wastewater systems sustainability in remote Australia (Faculty of Engineering University of Wollongong). Retrieved from http://ro.uow.edu.au/cgi/viewcontent.cgi?file name $=0 \&$ article $=4086 \&$ context $=$ theses $\&$ type $=$ additional

Widiastuti, D., Pramestuti, N., Setiyani, E., \& Rahayu, H. F. (2013). Mikroorganisme Patogen pada Feses Tikus. Kesmas: National Public Health Journal, $\quad 8(4), \quad$ 174-178. https://doi.org/10.21109/kesmas.v0i0.396

Yusuf, M. (2016). Model pengelolaan lingkungan estuaria sungai tallo kawasan perkotaan makassar.

Zainudin, N. (2019). Strategi Pengelolaan Limbah pada Instalasi Karantina Hewan (IKH) Ruminansia Yang Berkelanjutan. https://doi.org/10.1016/j.surfcoat.2019.12508 4 